\title{
LEITORAS DE CARNE E OSSO: A MULHER E AS CONDIÇÕES DE LEITURA NO BRASIL DO SÉCULO XIX
}

Regina Zilbeman $P \cup C-R S$

1. O século XVI foi um século de reformas: o sistema econômico orientou-se para o Mercantilismo, a sociedade aristocrática teve de acostumar-se com a presença, sempre incômoda, da burguesia e do dinheiro, monarcas absolutistas começaram a impor as teses que viriam a desembocar na teoria do direito divino dos reis. Mas Reforma foi o nome que tomou a grande transformação no campo religioso, estimulada por líderes revoltados com a centralização, ostentação e, segundo eles, corrupção do Papado, no Vaticano, que resistiu a essa crise, lutou contra ela e reagiu, através de um movimento, a Contra-Reforma, que, desde a denominação, sinaliza a aceitação, ainda que à revelia, dos grupos opositores. 
Outra reforma, a da educação, teve de aguardar o século XVII, devendo-se a demora, primeiramente, ao fato de ter sido desencadeada pelas ordens religiosas. Essas se ocuparam, no século XVI, com a conquista de adeptos entre os adultos. Protestantes ou jesuítas, aqueles na Europa e esses na América e Ásia, continentes alcançados pelas grandes navegações, se voltaram a algum tipo de catequese, pregando as novas idéias entre os católicos descontentes, como faziam os discípulos de Lutero e Calvino, ou angariando fiéis entre os habitantes originais das regiões descobertas.

No século XVII, o foco se altera, dirigindo-se para a formação da mocidade. Os jesuítas lideram, nos países católicos, a reforma das escolas e dos currículos, propondo um novo sistema de aprendizagem para as crianças, sobretudo as da ascendente burguesia, que precisavam de instrução e conhecimento, a fim de se adestrarem para a sociedade que os pais construíam. A outra razão para a reforma educacional ter de aguardar o século seguinte foi, portanto, o fato de ter sido necessário antes que a burguesia se fortalecesse e chamasse a atenção dos grupos religiosos, que se aliaram a ela e assumiram o papel de preparadores das novas gerações.

As duas reformas foram promovidas pelos mesmos segmentos. Os religiosos, porém, precisaram se convencer antes de que valia mais a pena enraizar a fé cristã no coração dos fiéis por meio da escola. Foi necessário, por outro lado, responder aos apelos da classe burguesa que lhes confiava a guarda dos meninos, na expectativa de que eles aprendessem lições que lhes auxiliassem, depois, a ocupar o lugar planejado por ela. O negócio foi proveitoso para ambos: a burguesia fornecia à Igreja clientela, e esta, da sua parte, recebia a instrução a aplicar no futuro.

As reivindicações em prol da educação da mulher são contemporâneas a esse movimento e associam-se a ele. Cabia adestrar a mulher para assumir as funções domésticas de que a nova camada emergente carecia, uma delas sendo não apenas a procriação, mas a educação das crianças. A burguesia não confia apenas na escola, pois precisa consolidar também as noções de lar e familia; para tanto, conta com a solidariedade da mulher, a quem compete preparar para as novas tarefas.

Na França, o movimento dispõe de um teórico, Fénelon, e um crítico, Molière, que se manifestou antes do outro, sugerindo que, quando o primeiro publicou seu Traité de l'éducation des filles, em 1687 , ia avançado o processo de formação da mulher. Molière, sobretudo em Les femmes savantes, de 1671, diverte-se, apresentando à platéia parisiense os perigos resultantes da nova situação: "As sabichonas" tomam conta da casa, submetem os maridos e abandonam as tarefas domésticas. Em Les précieuses ridicules, de 1658, Molière alerta para o risco de as jovens mostrarem pendores intelectuais: sonham com casamentos idilicos, recusam os prosaicos noivos burgueses e enlouquecem os pais outrora sensatos.

A educação das mulheres era vital para se consolidar a revolução burguesa, mas incidia em riscos, corporificados nos livros lidos, na cultura adquirida, na igualdade que se esboçava. Molière intui os dois lados da moeda e faz o público rir dos problemas que talvez tivesse em casa ou se revelariam no futuro. A instrução, concretizada em saber e ação, tornava-se perigosa e cabia advertir para a importância de se fixarem os limites e censurar os excessos.

O processo revolucionário burguês custou a chegar a Portugal e em terras de fala portuguesa. Em 1740 , constatam-se sinais de mudanças, sendo um deles a publicação do Verdadeiro método de estudar, de Luiz Antônio Verney, editado na Itália em 1746. Verney incorpora e difunde as novas idéias, adotadas durante o governo do Marquês de Pombal, que se empenha em implantar o sistema capitalista e em fortalecer a classe burguesa.

Verney advoga a necessidade de se instruírem as mulheres, argumentando que, enquanto mâes de familia, "são as nossas primeiras mestras nos primeiros anos da nossa vida". Elas ensinam a língua e "nos dão as primeiras idéias das coisas". O pedagogo acrescenta: "elas governam a casa, $e$ a direção do econômico fica na esfera da sua 
jurisdição". Recomenda também que leiam: "eu digo que ainda as casadas e donzelas podem achar grande utilidade na notícia dos livros". ${ }^{1}$ Visando concretizar suas idéias e dizendo-se inspirado em Fénelon e outros, sugere um currículo contendo estudos de religião, história, economia doméstica, trabalhos manuais e prendas de salão. Eis um programa de trabalho visando formar ética e praticamente a mulher, preparando-a para enfrentar os encargos no lar e na vida em sociedade, este sendo o âmbito da esfera pública que lhe era facultado.

Assim como se frustrou o projeto pombalino de modernização de Portugal, impedindo o país de se associar à revolução burguesa, fracassou a reforma educacional proposta pelo dirigente desde as idéias de Verney. Talvez as mulheres portuguesas tenham se beneficiado com as alterações; mas, no Brasil, o atraso continuou ao longo dos séculos XVIII e XIX, conforme o testemunho de viajantes de fora e intelectuais de dentro, com visíveis conseqüências, entre outras, no sistema literário.

2. A literatura foi uma das principais beneficiárias das modificações ocorridas no sistema educacional. Passou a dispor de um novo contingente de leitoras, a quem competia ficar em casa, porque a atividade pública lhe era vedada, e respondeu à nova situação com mudanças substanciais:

- aumentou o número de obras em prosa, de consumo mais fácil que os textos em verso, sobretudo os de tendência épica, como eram os gêneros nobres na Renascença;

- apareceram novos gêneros, como o romance e o folhetim, de trama prolongada e atraente;

- priorizaram-se enredos romanescos e de aventuras, herdeiros do roman courtois, mas dissociados da religião;

- deu-se ênfase à apreensão dos caracteres desde o ângulo interno, originando a narrativa psicológica;

- valorizou-se a personagem feminina enquanto protagonista e sujeito de grandes amores.

1. FERREIRA, Joaquim. Verdadeiro método de estudar, p.203 214.
Molière denuncia essas tendências em Les Précieuses ridicules, o que sugere sua popularidade já no século XVII e vínculo com a nova condição do público leitor, dominado em parte pelas preferências das mulheres. A educação delas, problema de caráter social, passa a ter peso econômico, ao gerar virtuais consumidoras de literatura. Mas ressoa ideologicamente, porque se torna matéria de discussão o tipo de leitura a ser destinado ou absorvido pelo público ascendente. Condenam-se gêneros e preferências, por produzirem efeitos supostamente deletérios; e acusa-se de vicioso o gosto de ler, por desviar a mulher das tarefas domésticas. A faca de dois gumes da educação começa a cortar, e a direção indesejada choca-se com a desejada, já que, se não convém a pais e maridos que as mulheres leiam muito ou leiam errado, editores e vendedores festejam os lucros advindos do novo comércio.

A questão da educação da mulher, desde as primeiras manifestações, repercute no âmbito literário: motiva mudanças estruturais nos textos, ascensão dos gêneros prosaicos e desaparecimento de expressões elevadas, afetando os modos de produção; e provoca discussões sobre os efeitos e vantagens da leitura, incidindo sobre os modos de circulação. O tema, de ordem econômica e ideológica, penetra no processo artístico, com conseqüências dignas de exame.

No Brasil, só se constatam essas conseqüências a partir do século XIX, após a separação de Portugal. A Independência motivou um projeto educacional para a nova nação, dentro do qual se incluía, ainda que marginalmente, o da instrução da mulher, que, como ocorreu na Europa, teve efeitos no âmbito da produção e circulação das obras dos escritores brasileiros.

O tema é, pois, relevante para a história da literatura brasileira. Para examiná-lo, recorre-se a depoimentos de época, presentes nos livros de viagens de visitantes estrangeiros e nas manifestações de artistas, intelectuais, professores e militantes brasileiros que se posicionaram perante o assunto. Os textos são analisados nessa perspectiva; dado o fato de eles não provirem de obras artísticas,

R. Est. Lit. Belo Horizonte, v. 1, n. 1, p. 31 - 47, out. 1993. 
não se aborda o ângulo estético. Nem por isso é menor a importância deles para a literatura brasileira, enquanto testemunho dos problemas que cercaram a manifestação e afirmação dela perante a sociedade nacional.

3. Os depoimentos, datados do século XIX, falam da falta de instrução da mulher brasileira, indicando a ignorância delas, má aparência, mau trato dos escravos e frivolidade. Os primeiros autores dessas denúncias foram viajantes estrangeiros que conheceram o Brasil antes da Independência. Em visita à terra, repelem a atitude dos homens em relação às mulheres, sejam esposas ou filhas, e a das mulheres em relação aos escravos, que fazem desses objeto ou de castigo ou de confidências, procedimentos ambos, segundo eles, impróprios para uma senhora.

Thomas Luccock, que esteve no Brasil no início do século, comentou o tratamento dado à mulher pela sociedade local:

Seria absurdo pretendermos a um relato igualmente detalhado das diferentes ordens de mulheres e de suas várias ocupações. Têm estas que ser, fatalmente, de natureza particular e é preciso que se lembre que as mulheres das classes altas e médias, e especialmente as mais moças, vivem muito mais reclusas que em nossa própria terra. $\mathrm{O}$ pouco contacto que os costumes com elas permitem, dentro em breve, põem a nu a sua falta de educação e instrução. (...) A ignorância que entre elas predominava, ao tempo em que vieram o Regente com seu séquito, era enorme, de todos reconhecida e muito lamentada pelos recém-vindos; transcorridos poucos anos, talvez que a coisa estivesse de algum modo remediada, mas a melhora não foi substancial. ${ }^{2}$

Henry Koster constata similar "estado de ignorância", ao que atribui o mau tratamento dado aos escravos, fato que o escandaliza. Sugere que

2.LUCCOCK, 1975. p. 75 se providencie na formação dessas mulheres, o que lhes possibilitará igualarem-se aos homens:

Sempre ouvi freqüentemente dizer, e não posso deixar de aceitar o reparo como exato na região do país de que estou tratando, que as mulheres são comumente menos humanas para com seus escravos que os homens, mas esse fato procede, indubitavelmente, do estado de ignorância no qual elas vivem. Recebem escassamente educação e não têm a vantagem de poder obter instrução pela comunicabilidade das pessoas estranhas ao seu ambiente nem adquirem novas idéias na conversação geral. (...) Levai essas mulheres para diante, educando-as; ensinai-lhes o que é racional, e serão iguais e em nada inferiores aos seus patrícios. A falta não está no sexo mas no estado dos costumes. ${ }^{3}$

Jean Baptiste Debret reclama que "desde a chegada da Corte ao Brasil tudo se preparara mas nada de positivo se fizera em prol da educação das jovens brasileiras. Esta, em 1815, se restringia, como antigamente, a recitar preces de cor $e$ a calcular de memória sem saber escrever nem fazer as operações.

Somente o trabalho de agulha ocupava seus lazeres, pois os demais cuidados relativos ao lar são entregues sempre às escravas". ${ }^{4}$ Depois da separação de Portugal, permaneceu a mesma situação, conforme E. Belman, para quem "a educação das meninas é negligenciada quase da mesma maneira e também elas são, em geral, deixadas aos cuidados das negras. Até se casarem quase nunca saem de casa, a não ser quando sob a vigilância da mãe vão à missa; a companhia dos homens lhes é absolutamente proibida, e este rigor as leva freqüentemente a se entregarem a uma negra de sua confiança, que por caridade cristã assume o honrado papel de alcoviteira (...)".5

3. KOSTER, 1942. p. 477.

4. DEBRET, 1954. p. 15.

5. BELMAN, 1984. p. 70 
ENSAIO

Edouard Manet, no período que passou no Rio de Janeiro, testemunhou igualmente a reclusão em que vivia a mulher brasileira:

Após o almoço, saí com meu novo amigo a percorrer a cidade. Ela é bastante grande, no entanto as ruas são bem pequenas; para o Europeu um pouco artista ela oferece um cunho bastante particular; só se vêem na rua negros e negras; os brasileiros saem pouco e as brasileiras ainda menos; só podem ser vistas quando vão à missa ou à tarde após o jantar; elas se põem à janela; é então permitido vê-las bem à vontade, pois, durante o dia, se por acaso estão à janela e percebem que as olhamos, elas se retiram imediatamente.

(...) As mulheres nunca saem sós, estão sempre acompanhadas de sua negra ou então com seus filhos, pois aqui casa-se aos 14 anos ou menos. ${ }^{6}$

Elizabeth e Luis Agassiz visitaram o Brasil entre 1865 e 1866 , constatando os mesmos problemas, retratados aqui:

Efetivamente, nunca conversei com as senhoras brasileiras com quem mais de perto privei no Brasil sem delas receber as mais tristes confidências acerca de sua existência estreita e confinada. Não há uma só mulher brasileira, que, tendo refletido um pouco sobre o assunto, não se saiba condenada a uma vida de repressões e constrangimento. Não podem transpor a porta de sua casa, senão em determinadas condições, sem provocar escândalo. A educação que lhes dão, limitada a um conhecimento sofrível de Francês e Música, deixa-as na ignorância de uma multidão de questões gerais: o mundo dos livros lhes está fechado, pois é reduzido o número de obras portuguesas que lhes permitem ler, e menor ainda o das obras a seu alcance em outras línguas. Pouca coisa

6. MANET, 1928, p. 51-3. sabem da história de seu próprio país, quase nada da de outras nações, e nem parecem suspeitar que possa haver outro credo religioso além daquele que domina no Brasil; talvez mesmo nunca hajam ouvido falar da "Reforma". Não imaginam que um oceano de pensamentos se agita fora de seu pequeno mundo e provoca constantemente novas fases na vida dos povos e dos indivíduos. Em suma, além do círculo estreito da existência doméstica, nada existe para elas. ${ }^{7}$

Que por todo o século XIX o problema persistiu, sugerem-no seja o fato de, a partir da década de 70 , intensificarem-se as campanhas em prol da educação feminina, seja a anotação de José Veríssimo, publicada em 1902, relativa ao problema, genérico, do analfabetismo no país:

As nossas avós, na máxima parte, não sabiam ler, e o número de analfabetos no Brasil, em 1890, segundo a estatística oficial, era, em uma população de 14.333.915 habitantes, de 12.213.356, isto é, sabiam ler apenas 16 ou 17 em cem brasileiros ou habitantes do Brasil. Difícil será, entre os países presumidos de civilizados, encontrar tão alta proporção de iletrados. ${ }^{8}$

4. Se "nossas avós" eram iletradas, o que faziam elas? Os depoimentos confirmam que ou não sabiam ler e escrever, ou seu conhecimento era limitado, visando reforçar a repressão doméstica. Explica Thomas Luccock:

Isto, aliás, fazia parte do sistema declarado; estava assentado que o saber ler para elas não deveria ir além do livro de rezas, pois que isso lhes seria inútil, nem tão-pouco se desejava que escrevessem a-fim-de que não fizessem, como sabiamente se observava, um mau uso dessa arte. ${ }^{9}$

7. AGASSIZ, 1975. p. 278.

8. VERÍSSIMO, 1977. p. 46

9. LUCCOCK, 1975, p. 75.

R. Est. Lit. Belo Horizonte, v. 1, n. 1, p. 31 - 47, out. 1993. 
ENSAIO

Jean Baptiste Debret confirma a prática pedagógica, revelando o modo de burlar a vigilância paterna:

Os pais e maridos favoreciam essa ignorância a fim de destruir pela raiz os meios de correspondência amorosa. Essa precaução, tão nociva aliás ao desenvolvimento da instrução, levou as brasileiras a inventarem uma combinação engenhosa de interpretação simbólica das diferentes flores, constituindo uma linguagem. ${ }^{10}$

E. Belman descreve a formação tendente ao frívolo da moça brasileira, destacando-se, em termos culturais, o conhecimento de música e de francês:

No Brasil, a moça bem educada, de boa formação (uma moça muito prendada) é aquela que com um pouco de música e de francês, sabe dançar um solo inglês, sabe bordar, fazer crochê e conhece a difícil arte de descascar, com gosto, uma laranja. ${ }^{11}$

A influência da cultura francesa, em especial, da literatura é acompanhada por Debret, que se refere a progressos após 1820 :

A partir de 1820 , a educação começou a tomar verdadeiro impulso e os meios de ensino multiplicaram-se de tal maneira de ano para ano que, já hoje, não é raro encontrarse uma senhora capaz de manter uma correspondência em várias línguas e apreciar a leitura, como na Europa.

A literatura francesa contribuiu bastante para isso, mediante uma seleção agradável de nossas obras morais traduzidas para a língua portuguesa; esses livros, que se tornaram clássicos, interessam pela sua novidade, ornam o espírito e formam o coração das jovens alunas brasileiras. ${ }^{12}$

\footnotetext{
10. DEBRET, 1954., p. 16.

11. BELMAN, 1984., p. 70-1.

12. DEBRET, 1954., p. 16.
}

Nem assim as mulheres integram-se verdadeiramente ao horizonte da cultura elevada. Em $O$ Brasil e os brasileiros, de 1851, os autores criticam a tendência das moças a lerem romances açucarados e folhetins tolos:

As maneiras e os costumes das damas brasileiras são gentis, e seu porte gracioso. É verdade que não têm uma base de conhecimentos variados para tornar agradável e instrutiva a sua palestra; mas tagarelam insignificâncias de modo sempre agradável, exceto pelo alto tom de sua voz, que eu suponho lhes venha das ordens freqüentes que dá aos congos e moçambiques. Suas reservas literárias consistem principalmente em novelas de Balzac, Eugenio Sue, Dumas, pai e filho, George Sand, em intrigas de pacotilhas e folhetins dos jornais. Assim elas se preparam para esposas e mâes. ${ }^{13}$

A mesma censura, e na mesma época, provém de Charles Expilly, em Mulheres e costumes do Brasil:

Hoje ainda a educação de uma brasileira está completa, desde que saiba ler e escrever correntemente, manejar o chicote, fazer doces e cantar, acompanhando-se ao piano, num romance de Arnaud ou de Luíza Puget. Até agora as senhoras não tomaram da civilização senão a crinolina, o chá e a polca. ${ }^{14}$

José Verissimo, em $A$ educação nacional, de 1890 , reitera a crítica:

Tudo o mais que lhe ensinassem além deste programa seria acessório e subsidiário. As línguas estrangeiras, afora a sua utilidade prática imediata, só lhe serviriam como fatores de educação se com elas lhe ensinassem a ler, a apreciar as grandes obras, honra do espírito humano, destas línguas, e não somente os romances folhetins ou sentimentais

13. KIDDER; FLETCHER, 1941. p. 181.

14. EXPILLY, 1935. p. 405. 
ENSAIO

dos Bourgets e sócios, ou a se poderem edificar ouvindo as Réjanes e quejandas cabotinas, em jornadas teatrais por países exóticos. ${ }^{15}$

Somente Machado de Assis, talvez por ter se iniciado como escritor nesse tipo de publicação e se dirigido ao público criticado por Kidder \& Fletcher e Expilly, aceita a literatura amena, como a editada no Jornal das Famílias, onde colaborava:

Melhorando de dia para dia, as edições da casa Garnier são hoje as melhores que aparecem entre nós.

Não deixarei de recomendar aos leitores fluminenses a publicação mensal da mesma casa, o Jornal das Familias, verdadeiro jornal para senhoras, pela escolha do gênero de escritos originais que publica e pelas novidades de modas, músicas, desenhos, bordados, esses mil nadas tão necessários ao reino do bom-tom.

O Jornal das Famílias é uma das primeiras publicações deste gênero que temos tido; o círculo de seus leitores vai se alargando càda vez mais, graças à inteligente direção do Sr. Garnier. ${ }^{16}$

Elizabeth Agassiz, na Viagem ao Brasil 18651866, encara a questão com olhos diferentes dos outros viajantes. Critica duramente a leitura aconselhada, pelos homens, às mulheres, de tipo moralista e insossa, provavelmente a que Kidder \& Fletscher ou Expilly desejariam, entendendo a razão de elas fugirem dos livros. Expõe sua crítica ao narrar o seguinte episódio:

Estávamos um dia numa fazenda, quando avistei um livro em cima de um piano. Um livro é coisa tão rara nos aposentos ocupados pelas famílias que fiquei curiosa em saber qual seria o conteúdo dele. Era um ro-

15. VERISSIMO, 1985. p. 129.

16. ASSIS, 1959. p. 264-5. mance, e, ao virar-lhe as páginas, veio o dono da casa e disse em alta voz que aquela não era uma leitura conveniente para mulheres. - "Aqui está (entregando-me um pequeno volume), uma excelente obra que comprei para minha mulher e minhas filhas." Abri o precioso volume, era uma espécie de tratado de moral, cheio de banalidades sentimentais e de frases feitas em que reinava um tom de condescendência e proteção à pobre inteligência feminina, porquanto, apesar de tudo, as mulheres são mâes dos homens e exercem um pouco de influência sobre sua educação. Após essa mostra do alimento intelectual que lhes ofereciam, não me poderia admirar que a esposa e as filhas do nosso anfitrião demonstrassem um gosto dos mais moderados pela leitura. Nada impressiona tanto o estrangeiro como essa ausência de livros nas casas brasileiras. Se o pai exerce uma profissão liberal, tem pequena biblioteca de tratados de Medicina ou Direito; mas não se vêem os livros espalhados pela casa como objetos de uso constante, não fazem parte das coisas de necessidade corrente. ${ }^{17}$

Machado de Assis, na mesma época, igualmente verifica a ausência de livros nos lares brasileiros, ironizando suas causas:

Que pouco se leia nesta terra é o que muita gente afirma, há longos anos, é o que acaba de dizer um bibliômano na Revista Brasileira. Este, porém, confirmando a observação, dá como uma das causas do desamor à leitura o ruim aspecto dos livros, a forma desigual das edições, o mau gosto, em suma. Creio que assim seja, contanto que essa causa entre com outras de igual força. Uma destas é a falta de estantes. As nossas grandes marcenarias estão cheias de móveis ricos, vários de gosto; não há só cadeiras, mesas, camas, mas toda a sorte de trastes de adomo, fielmente copiados dos modelos

17. AGASSIZ; CARY, 1975., p. 278-9. 
franceses, alguns com o nome original, o $b i$ jou de salon, por exemplo, outros em língua híbrida, como o porta-bibelots. Entra-se nos grandes depósitos, fica-se deslumbrado pela perfeição da obra, pela riqueza da matéria, pela beleza da forma. Também se acham lá estantes, é verdade, mas são estantes de música para piano e canto, bem acabadas, vário tamanho e muito maneiras.

Ora, ninguém pode comprar o que não há. Mormente aos noivos, nem tudo acode. A -prova é que, se querem comprar cristais, metais, louça, vão a outras casas, assim também roupa branca, tapeçaria, etc.; mas não é nelas que acharão estantes. Nem é natural que um mancebo, prestes a contrair matrimônio, se lembre de ir a lojas de menor aparência, onde as compraria de ferro ou de madeira; quando se lembrasse, reflitiria certamente que a mobilia perderia a unidade. Só as grandes fábricas poderiam dar boas estantes, com ornamentações, e até sem elas. ${ }^{18}$

A ressalva manifestada por Elizabeth Agassiz não deixa de revelar que Machado tinha razão, ao abordar $\mathrm{o}$ assunto:

Repito que há exceções; lembro-me de ter encontrado, no quarto duma jovem senhora cuja familia nos dera afetuosa hospitalidade, uma biblioteca bem escolhida das melhores obras de história e literatura, em francês e alemão; mas foi o único exemplo desses que encontramos durante um ano de permanência no Brasil. Mesmo quando as brasileiras receberam os benefícios da instrução, há, em sua existência doméstica, tanta compressão, tão pouco estão em ligação com o mundo exterior, que isso basta para pôr obstáculo a seu desenvolvimento intelectual; seus prazeres são tão mesquinhos e raros como seus meios de instrução. ${ }^{19}$

18. ASSIS, 1959. p. 414-5.

19. AGASSIZ; CARY,1975., p. 279.
O universo da leitura da mulher brasileira é dos mais restritos. Iletrada na maioria dos casos, faz parte de uma sociedade para a qual o livro, a leitura e a cultura não parecem apresentar maior significado. Quando recebe educação formal, esta prima pela superficialidade. Conforme aponta Moritz Lamberg, quase ao final do século XIX,

Assim que [as moças] conseguem pronunciar algumas frases em francês e arranhar piano, está terminada a sua educação. Saem da escola e são moças, que os pais, com o máximo cuidado, preservam de qualquer contato com os homens.

O comércio livre entre uma mulher espirituosa e instruída e amigos, como há em todos os países civilizados, não é permitido aqui. Os homens são por demais ciumentos e desconfiados.

A ocupação doméstica das mulheres, quando se ocupam de alguma coisa, consiste na leitura de romances, que nem sempre são dos mais escolhidos, e em inúmeras futilidades. ${ }^{20}$

Ela consome folhetins e romances ligeiros, que imprensa e editoras lhes oferecem; mesmo essa leitura, porém, é diminuída, seja porque as obras são consideradas de má qualidade, seja porque desejável seria que lessem textos mais elevados, insossos, contudo, e desestimulantes. As opções são ralas, o que suscita a militância de muitos, especialmente mulheres, no sentido de estimular a educação feminina em melhores termos, argumentando ser essa a condição para a estabilização da vida familiar no Brasil e seu progresso.

5. A mais conhecida militante em prol da educação feminina, no século XIX, foi Nísia Floresta. O Opúsculo Humanitário, de sua autoria, é inteiramente dedicado ao tema, proclamando a necessidade de se formar e instruir a mulher, a fim de que ela possa assumir suas funções na sociedade. ${ }^{21}$

20. LAMBERG, 1984., p. 85-7.

21. Cf. AUGUSTA. Opúsculo humanitário. (mimeo) 
ENSAIO

Nos Conselhos à minha filha, de 1842, ela sintetiza suas idéias, vendo na busca do saber e conquista do conhecimento a condição de a mulher ter reconhecido seu valor no mundo dos homens:

Se procuro abrir-te, e facilitar-te o caminho das ciências, se me esforço por dar-te uma educação, que entre nós se nega ao nosso sexo, é sem dúvida na esperança de que a minha cara filha, bebendo as saudáveis lições da sabedoria, procure dar um dia a seu espírito o realce das virtudes que tanto o enobrecem, e que é o único a torná-lo digno da estima e respeitos da sociedade. E como não pretendo limitar-me a dar apenas a teu espírito uma leve notícia da ciência, que, diz o vulgo, não ser necessária à mulher, eu não temo que a vaidade, vício desprezível, que geralmente se atribui ao nosso sexo, infeccione tua alma. ${ }^{22}$

No Discurso que às suas educandas dirigiu N.F. $B$. Augusta, reforça a convicção de que a instrução fortalece a mulher:

Felizes aquelas que, tendo como vós Pais que, curando de vossa felicidade futura, facilitam-vos os meios de cultivardes o vosso espírito, e lições que tendem a aperfeiçoálos, sabem aproveitar o tempo precioso dos estudos, e fazer bom uso de uma instrução, de que tanto precisa o nosso sexo, a fim de facilmente preencher os sagrados deveres que lhe impõem a natureza e a sociedade; e forças, por assim dizer, o egoísmo, a discriminar nele o mérito que lhe dá uma sólida instrução, da desprezível vaidade, que não pode afluir senão em espíritos nimiamente medíocres. ${ }^{23}$

Militante foi também Luciana de Abreu, que, em 1875 , proferiu palestra sobre a "Educação das mâes de família", afirmando a igualdade dos sexos e reivindicando, como Nísia Floresta, a instrução

22. AUGUSTA, 1845. p. 16-7.

23. AUGUSTA, 1847. da mulher, para ela exercer a contento suas tarefas na sociedade:

Nós não somos somenos ao homem; a nossa alma tem a mesma passividade e atividade que a dele, e tanto a sensibilidade como a inteligência e a liberdade participam do mesmo grau de capacidade e podem ter o mesmo grau de desenvolvimento num ou noutro sexo.

$\mathrm{O}$ que convém pedir, o que venho em vosso nome altamente reclamar, é, de parceria com a educação, a instrução superior comum a ambos os sexos; é a liberdade de esclarecer-nos, de exercer as profissões a que as nossas aptidões nos levarem.

Dêem-nos educação e instrução; nós faremos o mais. A nossa posição legítima na sublime missão de que estamos incumbidas, nós a tomaremos pelo nosso trabalho, e a humanidade há de tudo ganhar com o nosso triunfo. ${ }^{24}$

Na conferência sobre a "Emancipação da mulher", reforça a idéia de que compete a mulher, enquanto mãe, educar os filhos, razão para se tomarem providências no sentido de sua formação: "só a mulher culta e moral saberia resolver com vantagem os dificeis problemas da instruçâo universal, do luxo em relação à posição pecuniária do indivíduo; e que só ela poderia plantar no coração da mocidade os sãos princípios da ordem na liberdade. ${ }^{125}$

José Veríssimo, em $A$ educação nacional, endossa a proposta e observa que "cumpre, em suma, tirar a mulher brasileira da quase ignorância em que a sua imensa maioria jaz (...). Não esqueçamos jamais que é ela a primeira e imediata educadora do homem e, para educar, a primeira condição é saber. ${ }^{26}$

24. ABREU, 1949. p. 17-9.

25. ABREU, 1949., p. 25.

26. VERÍSSIMO, 1985. p. 129. 


\section{ENSAIO}

A Mensageira, jornal feminista impresso em São Paulo, alardeia em seus artigos idéia semelhante, a que dá configuração patriótica, ao atribuir ao sucesso da empresa de educação da mulher a transformação da sociedade e o progresso da nação. Eis algumas dessas manifestaçōes:

É de grandioso alcance a fim de obter-se a grandeza da pátria e mesmo a felicidade do gênero humano, trabalhar-se a favor da educação da mulher, assim como da sua emancipação, conferindo-se-lhe as mesmas prerrogativas que ao homem são concedidas.

Instruída, que seja, a sociedade se transformará completamente. ${ }^{27}$

Não basta que compreendamos a utilidade e os atrativos do espírito cultivado, é mister que façamos de nossa parte o maior esforço possível, procurando instruir-nos e desenvolver-nos a bem da pátria e da família.

Quanto mais ilustrada e inteligente for uma mulher, tanto mais zelosa e cumpridora de seus deveres será. ${ }^{28}$

No poema "Saudação", Cruz e Sousa desenvolve princípio similar, considerando a mulher educadora. Mas acrescenta-lhe a idéia de que, por ensinar, a mãe é também professora; a recíproca vale também, e a professora é desdobramento da mãe:

Ah! Ninguém sabe, por certo, quanto é bom, quanto é saudável, sentir a crença adorável como um clarão sempre aberto.

Ver os germens do futuro no campo eterno da escola brilhando como a corola de um lírio cândido e puro.

Ver morrer - como uns invernos da vida, os velhos colossos e ver erguerem-se os moços como verões sempiternos.

Mães, ó mães tão estremosas, dos vossos ventres fecundos saem todos esses mundos das idéias fulgurosas.

Tudo isto quanto há escrito do pensamento e crenças saiu das fontes imensas de um grande amor infinito.

E desde a escrita à leitura e desde um livro a uma carta, a bondade sempre farta das mães - esplende e fulgura.

Bom dia ao mestre que é guia das belas crianças louras! Bom dia às mães porvindouras, à mocidade - Bom dia! ${ }^{29}$

No texto de Cruz e Sousa, observa-se uma transição que revela, não intencionalmente, o fundo ideológico do projeto de educação da mulher. Esse projeto, desde seu nascimento, fez parte da revolução burguesa, que, no Brasil, começa a tomar corpo após os anos 70, época em que se intensificam as campanhas a favor da instrução feminina. $\mathrm{O}$ enriquecimento decorrente da exportação do café favorece a emergência de segmentos urbanos, o fortalecimento da classe média e a modificação dos setores dirigentes, ainda associados à propriedade da terra, mas agora interessados no comércio exterior. Os novos grupos não se satisfazem com a fisionomia política, econômica e cultural do país, julgada conservadora e ultrapassada; querem modificá-la, tornando a nação moderna e civilizada, adaptada às inovações tecnológicas, os novos costumes e o progresso, característicos do final do século.

Compete remover os elementos arcaicos enraizados na sociedade e remanescentes da vida colonial, sendo um deles o estado de reclusão e atraso da população feminina, o outro, o analfabetismo da maior parte da população, crianças e adultos.

29. SOUSA, 1981. p. 249-51. 
ENSAIO

A campanha favorável à educação da mulher veio acompanhada de outra, visando à obrigatoriedade do ensino para as crianças, atitude a ser encampada e imposta pelo Estado.

$O$ fato de que, em ambos os casos, se tratava de instruir, aproxima as duas campanhas. Elas se aparentam também porque formar a mulher era ser prático, ao se diplomarem contingentes de professoras à disposição do mercado. A mulher, em princípio, educava os filhos; seria também a mestra de todos, estendendo para fora de casa a tarefa para a qual fora talhada. Abria-se um campo profissional para a mulher, mas que já nascia aviltado, porque o reconhecimento era pequeno ensinar passou a ser visto como algo feminino, portanto, menor - e o pagamento, insuficiente, aceitável apenas quando complementar à renda principal, a do homem - pai ou marido - que sustentava o lar.

Destinar a mulher ao magistério resolvia vários problemas: justificava a necessidade de educá-la; solucionava o problema da falta de mão de obra para o magistério, profissão pouco procurada por mal remunerada; não carecia melhorar os proventos, porque o salário da mulher não deveria ser superior ao do homem, e sim adicional. Essas razões estavam recobertas por outras, de caráter ideológico: idealizava-se a professora, chamandoa de mãe e, assim, sugerindo que, ensinando, ela continuava fiel à sua natureza maternal; negava-se o elemento profissional da docência, porque a sala de aula convertia-se num segundo lar; ensinar não seria problema, porque não era trabalho, e sim extensão das tarefas domésticas, o que sustava o eventual pendor emancipatório que essa atividade poderia conter e não contradizia a índole machista da sociedade patriarcal brasileira; e permanecia intocada, e também idealizada, a associação mulher-esposa-mãe, mesmo quando essa estịvesse fora de casa, ganhando o modesto pão de cada dia.

Em alguns autores, a relação é mais claramente expressa, como faz Oliveira Belo:
O segredo desse sistema consiste em tornar a escola simpática às crianças, fazendo-a carinhosa como a casa materna; em vez da disciplina pelo rigor, que amedronta e afasta, a ordem pela amizade, que granjeia e retém; em vez da aula taciturna, monótona, ríspida como a alcova de um mosteiro na qual o espírito jovial da infância se estiolava nas sombras úmidas de uma estufa, em vez do cenho carregado e minaz do pedagogo, que se afigurava um verdugo às imaginações intimoratas dos discípulos, um lar ameno, $\mathrm{ri}^{-}$ sonho, encantador, com a alegria de ressumbrar de toda a parte e uma palavra amiga, complascente, infundindo as iniciações do ensino com esse zelo paciente $\mathrm{e}$ bondoso, com que a ternura da mãe-defamilia insinua na inteligência dos filhos os primeiros conselhos da moral e as balbuciantes invocações do Deus da infância.

Era mister, porém, descobrir quem ocuparia esse posto delicado do magistério, quem teria em si encanto e força para transformar a escola em lar doméstico e a instrução primária em carinhosa educação das inteligências infantis; não foi difícil resolver o problema, confiou-se a infância ao coração feminino, a mulher assumiu o berço do ensino, fez-se mãe-de-família na escola. ${ }^{30}$

Os esforços visando à emancipação feminina não fogem ao processo de dominação da mulher pela sociedade burguesa. Mesmo entre as militantes, enquadram-se aos ideais familistas que, até então, tinham impedido a mulher de se liberar. Agora, ela pode receber instrução e trabalhar, mas seu universo é o da família, da casa e do marido, ao qual cabe se dedicar.

As leituras a que é aconselhada adequam-se a essa moldura. Folhetins ou histórias de fantasia são desaprovados, porque iludem e afastam a leitora das tarefas domésticas. Preferiveis são as obras de moral e religião, que devolvem a mulher para sua atividade principal.

30. BELO, 1875. 


\section{ENSAIO}

Esse é o conselho de Júlia Lopes de Almeida às moças, no Livro das noivas, manual destinado à preparação da futura esposa e mâe. No capítulo dedicado à leitura, ela nega que os livros possam ser nocivos, nesse ponto irmanando-se às teses que propugnavam a formação e instrução da mulher:

Os pais antigos proibiam a leitura às filhas, afirmando que os livros eram os piores inimigos da alma.

Para livrarem então as pobres inocentes de, por qualquer casualidade, entrarem um dia em contato com tão perigosos conselheiros, faziam uma coisa que lá consigo julgavam muito acertada - não as ensinavam a ler! Era, evidentemente, o meio mais coercitivo.

Hoje em dia o não saber ler é, felizmente, considerado uma vergonha, e não há uma pessoa que propositalmente condene os filhos a tamanha desgraça; agora o que ainda há são chefes de familia que abominam os livros, ordenando às filhas que não toquem nunca em semelhante coisa. ${ }^{31}$

Sua postura é outra, recomendando o contato com os livros. Mas restringe as leituras, censurando obras que não tenham fundo moral ou pragmático e sejam escapistas. Lamenta, porém, que esta não seja a regra, predominando, pelo contrário, "novelas prejudiciais, insalubres, recheadas de aventuras românticas e de heróis perigosos". ${ }^{32}$ Suas palavras reproduzem a crítica de autores e pedagogos preocupados com os livros consumidos pelas mulheres brasileiras desde o início do século XIX: ${ }^{33}$

\section{ALMEIDA, 1895. p. 35.}

32. Id. ibidEM., p. 36.

33. E que permanecem vivas na primeira parte do século $\mathrm{XX}$, pelo menos, conforme se pode deduzir das lembranças de $\mathrm{D}$. Brites, nascida em 1903: "Líamos Júlio Diniz, A morgadinha dos canaviais, As pupilas do Sr. Reitor, eu adorei Uma familia inglesa, tinha uma paixão pelo Carlos! depois apareceu a Bibliotèque Rose que os pais costumavam dar às filhas, toda em francês. Guy de Chantepleure, Titio, o Sr. Vigário, que era engraçadissimo... não sei de quem era... uma menina espeloteada que namorava o primo e embrulhava o vigário que era professor
Quem está acostumado a uma leitura sadia, às obras dos mestres, não suporta a linguagem pervertedora dos romances maus.

Mas, desgraçadamente, nós não sabemos ler!

É raro encontrarem-se nas nossas salas duas senhoras que falem de literatura, mostrando interesse pelos bons autores, principalmente pelos do seu país! Do jomal lêem o folhetim, isto é, o romance de enredo, onde as deleitam as cenas imprevistas, as astúcias de lacaios e de agentes falsos, os véus negros de adúlteras em entrevistas amorosas, e os lampejos de espadas no campo de honra! ${ }^{34}$

Júlia Lopes de Almeida valoriza a leitura, afirmando que "o livro é um amigo; nele temos exemplos e conselhos, nele um espelho onde tanto as nossas virtudes como os nossos erros se refletem. Repudiá-lo seria loucura; escolhê-lo é sensato". ${ }^{35}$ Mas as leituras precisam ser selecionadas, para preencherem a função a que se destinam, a de ajudar a mulher na educação dos filhos e manutenção do lar, tarefa que lhe compete, sendo casada:

A estante de uma mulher de espírito e de coração, isto é, de uma mulher habilitada a aprender e conservar o que ler; que souber que isso a instrui, a torna apta para dirigir a educação dos filhos, dando-lhe superioridade e largueza de vistas; a estante de uma mulher inteligente e cuidadosa, que ama os seus livros, não como um mero adorno de gabinete, mas como a uns mestres sempre consoladores e sempre justos, essa estante é um altar onde o seu pensamento vai, cheio de fé, pedir amparo numa hora de desalento, e conselho num momento de dúvida.

dela. A gente chorava de rir com as mentiras de Tartarin de Tarascon. Eça de Queirós nāo se lia ainda. De Machado de Assis podia-se ler Helena, mas Brás Cubas não." Cf. Bosi, 1981. p. 251 .

34. ALMEIDA, 1895. p. 36-7.

35. Ibidem, p. 38 . 
Aprender para ensinar! eis a missão sagrada da mulher.

É preciso para isso que a sua leitura seja sã, bem feita. $O$ gosto bem educado transmitirse-á sem mácula e sem esforço aos filhos.

Convençamo-nos de que o espírito, para dominar, deve ter sido dominado pela força suprema e bendita dos que são mais fortes ou trabalham mais. ${ }^{36}$

Eis por que encerra com uma convocação:

Vamos! minhas amigas, comecemos a ler, mas com cuidado. ${ }^{37}$

A ordem dada pela autora limita, mais uma vez, o universo de circulação do livro. O preconceito de que se revestia a escrita e a leitura, quando, no início do século, pais e maridos impediam filhas e esposas de aprenderem a escrever e ler, repete-se aqui, adaptado ao contexto da sociedade do final do século. Escrever e ler são obrigatórios, mas ficam condicionados às necessidades - agora pedagógicas - dos mesmos senhores de então.

Não por acaso Júlia Lopes de Almeida narra o medo e a apreensão que cercaram suas primeiras incursões literárias:

Pois eu em moça fazia versos. Ah! não imagina com que encanto. Era como um prazer proibido! Sentia ao mesmo tempo a delicia de os compor e o medo de que acabassem por descobri-los. Fechava-me no quarto, bem fechada, abria a secretária, estendia pela alvura do papel uma porção de rimas...

De repente, um susto. Alguém batia à porta. $\mathrm{E}$ eu, com a voz embargada, dando volta à chave da secretária: já vai! já vai! ${ }^{38}$

Fruto das mobilizações visando à instrução feminina e da necessidade de formação de professoras,

36. ALMEIDA, 1895. p. 38-9.

37. Ibidem, p. 39.

38. RIO, (s. d.) p. 23. as mulheres acabaram por constituir-se num grupo de consumidoras dignas de atenção. Leitoras com exigências próprias e escritoras ativas, não podiam ser ignoradas ou marginalizadas. A sociedade, todavia, tratou de controlá-las, usando de alguns mecanismos: converteu o magistério numa extensão da tarefa doméstica e maternal e desqualificou o trabalho delas aos olhos masculinos; desvalorizou suas leituras, embora não deixasse de fornecêlas em quantidades substanciais e crescentes; condicionou a recepção de obras às necessidades de doutrinação desse público, que reabsorveu valores familistas e patriarcais, traduzidos agora na linguagem da idealização da mulher e de sua tarefa doméstico-pedagógica.

No texto de Júlia Lopes de Almeida, estão presentes esses atributos. Ela direciona as leitoras para livros sadios, afirma a missão educativa da mulher dentro do lar e reitera a desconfiança perante as más leituras. A escritora reproduz o processo tal como ele se constitui desde suas origens, no século XVII. Também então se reforçou a noção de que a sociedade carecia de mulheres instruídas, educadas, porém, para as necessidades do grupo social, e não da própria mulher. Este risco foi percebido por Molière, que soou o alarme, seguido desde então, até pelo menos o momento, no Brasil, em que a emancipação feminina era uma possibilidade no horizonte delas mesmas e precisava ser contida. A leitura que significaria a liberação mais uma vez, repetindo-se a observação de Elizabeth Agassiz, serviu ao seu contrário, tornandose algo a evitar. A sociedade de iletrados preferiu ser letrada pela metade, sacrificando o crescimento da literatura e de seu público às exigências de manutenção do status quo.

6. A maior parte dos depoimentos documenta a pouca ou quase nenhuma leitura na vida das mulheres brasileiras. Elas raramente se manifestam e, quando o fazem, expressam sua militância em favor da educação e maior participação feminina na sociedade. Instruída, ela poderá se tornar boa leitora, mas igualmente essa meta é objeto do controle social, expresso na escolha dos livros. 
ENSAIO

Esses são raramente citados. Mas as situações de leitura existiram, porque documentadas. José de Alencar recorda sua tarefa de ledor, quando criança, arrancando lágrimas do auditório:

Essa prenda que a educação deu-me para tomá-la pouco depois, valeu-me em casa o honroso cargo de ledor, com que me eu desvanecia, como nunca me sucedeu ao depois no magistério ou no parlamento.

Era eu quem lia para minha boa mãe não somente as cartas e os jornais, como os volumes de uma diminuta livraria romântica formada ao gosto do tempo.

Não havendo visitas de cerimônia, sentavase minha boa mãe e sua irmã D. Florinda com os amigos que parecia, ao redor de uma mesa redonda de jacarandá, no centro da qual havia um candeeiro.

Minha mãe e minha tia se ocupavam com trabalhos de costuras, e as amigas para não ficarem ociosas as ajudavam. Dados os primeiros momentos à conversação, passava-se à leitura e era eu chamado ao lugar de honra. (...)

Lia-se até a hora do chá, e tópicos havia tão interessantes que eu era obrigado à repetição. Compensavam esse excesso, as pausas para dar lugar às expansões do auditório, o que desfazia-se em recriminações contra algum mau personagem, ou acompanhava de seus votos e simpatias o herói perseguido.

Uma noite, daquelas em que eu estava mais possuído do livro, lia com expressão uma das páginas mais comoventes da nossa biblioteca. As senhoras, de cabeça baixa, levavam o lenço ao rosto, e poucos momentos depois não puderam conter os soluços que rompiam-lhes o seio.

Com a voz afogada pela comoção e a vista empanada pelas lágrimas, eu também cerrando ao peito o livro aberto, disparei em pranto e respondia com palavras de consolo às lamentações de minha mãe e suas amigas.

Nesse instante assomava à porta um parente nosso, o Revdo Padre Carlos Peixoto de Alencar, já assustado com o choro que ouvira ao entrar - Vendo-nos a todos naquele estado de aflição, ainda mais perturbou-se:

- Que aconteceu? Alguma desgraça? Perguntou arrebatadamente.

As senhoras, escondendo o rosto no lenço para ocultar do Padre Carlos o pranto e evitar seus remoques, não proferiram palavra. Tomei eu a mim responder:

- Foi o pai de Amanda que morreu! Disse, mostrando-lhe o livro aberto.

Nosso repertório romântico era pequeno; compunha-se de uma dúzia de obras entre as quais primavam a Amanda e Oscar, Saint-Clair das Ilhas, Celestina e outras que já não me recordo. ${ }^{39}$

Alencar desenha o painel da leitura romântica, dominada pelo folhetim, quando reinam incontestadas obras como o Saint-Clair das Ilhas. O quadro é doméstico, dominado pela leitura oral e a participação coletiva, de preferência mulheres que se comovem perante cenas sentimentais. Esse modelo de transmissão de histórias parece bastante primitivo, remontando às manifestações mais antigas e populares da arte de contar, as mesmas que Walter Benjamin valoriza em seu estudo sobre o narrador e que considera raiz e origem da narrativa, perdidas com a evolução da tecnologia e o isolamento das pessoas. ${ }^{40}$

Essa primitividade condiz, de um lado, com as condições de vida da sociedade brasileira da primeira metade do século XIX. Alencar não esclarece se as ouvintes poderiam ler sozinhas as obras, mas teriam preferido experimentar juntas, e de

39. ALENCAR, 1990. p. 24-9.

40. Cf. BENJAMIN, 1985. 
ENSAIO

modo participativo, a recepção das histórias. $\mathrm{O}$ contexto sugere, por outro lado, que as opções de leitura eram poucas e pobres; e que essas mulheres estavam reclusas em casa, repetindo-se o panorama descrito antes.

A mesma primitividade condiz, de outro lado, com a situação original de audição de histórias, valorizada por Walter Benjamin, perdida pela expansão do processo de leitura solitária e recuperada modernamente em certas condições propiciadas pelo aperfeiçoamento tecnológico dos meios de comunicação de massa. Ao contrário do que talvez esperasse Walter Benjamin, o rádio, especialmente no seu apogeu dos anos 40 e 50, e a televisão, depois disso, refazem, à sua moda, o modelo da transmissão oral de histórias, razão talvez de sua popularidade.

Alencar, ledor que reproduziu o narrador primitivo idealizado por Walter Benjamin, conheceu as atitudes e as reações do público leitor feminino bem antes de escrever para ele. Ele mesmo cogita se as cenas domésticas não teriam influenciado o futuro ficcionista: "essa mesma escassez, e a necessidade de reler uma e muitas vezes o mesmo romance, quiçá contribuiu para mais gravar em meu espírito os moldes dessa estrutura literária, que mais tarde deviam servir aos informes esboços do novel escritor". 41

Seus romances, tais como os de Machado de Assis, que representa, na ficção, cenas similares à esboçada por Alencar, destinam-se, porém, à leitura individual. Talvez tivessem sido lidos conforme descreve Graça Aranha, que também relembra a mãe, leitora inveterada e, segundo o filho, de bom gosto:

Deliciosos serões com minha mâe. Ela era uma grande devoradora de romances. Quando as provisões que o carinho de meu pai sempre entretinha, se extinguiam, havia o recurso da biblioteca do Gabinete Português de Leitura. A velha Militina era a mensageira dos livros. Minha mãe dispensava

41. ALENCAR, 1990. p. 29-30. nas noites de novidade literária acompanhar meu pai às suas visitas. As crianças estavam recolhidas. Só eu velava ao seu lado. Enquanto ela absorta lia, eu ensaiava escrever dissertações de filosofia e de direito, que eram reminiscências das colheitas das lições de Tobias Barreto. Raramente éramos interrompidos, porque, segundo os costumes, as visitas se anunciavam pelas criadas que, durante o dia, vinham "tirar licença" para as suas senhoras. O que apareciam às vezes, eram pedintes, sempre socorridos. Ou então a visita de duas velhinhas esqueléticas e miúdas. Minha mãe repousava o livro e as ouvia complascente. Vinham vender bonecas de pano que faziam. ${ }^{42}$

Poucos autores vêem com benevolência cenas como esta. A admiração de Graça Aranha seguidamente é substituída pela censura, que condenaria essa senhora por deixar de acompanhar o marido e entregar-se ao prazer, solitário e egoísta, propiciado pelo livro lido. Porque esse prazer, conforme os padrões da sociedade brasileira, estava vedado às mulheres, a quem competia instruir-se para servir à família.

Ao final do século, ainda a leitura é atividade rara $\mathrm{e}$, em muitos casos, condenável. As mulheres constituem indubitavelmente um público ascendente, manipulado por homens que escrevem; ou então prescrevem regras, a que se submetem na maioria dos casos. Caberia ver como os ficcionistas reagem, tendo de lidar com a dubiedade e a contradição trazidas desde as primeiras manifestações em prol da formação feminina, no século XVII francês.

\section{REFERÊNCIAS BIBLIOGRÁFICAS}

1. ABREU, Luciana de. Preleções. Prefácio, estudo e coletânea de Dante de Laytano. Porto Alegre: Museu Júlio de Castilhos, 1949. p. 17 - 19: Educação das mães de familia; p. 25: Emancipação da mulher.

42. ARANHA, 1931. p. 167-8.

R. Est. Lit. Belo Horizonte, v. 1, n. 1, p. 31 - 47, out. 1993. 
ENSAIO

2. AGASSIZ, Luiz, CARY, Elizabeth. Viagem ao Brasil; 1865 - 1866. Belo Horizonte: Itatiaia; São Paulo: Edusp, 1975.

3. ALENCAR, José de. Como e porque sou romancista. Adapt. ortográfica de Carlos de Aquino Pereira. Campinas: Pontes, 1990.

4. ALMEIDA, Júlia Lopes de. O livro das noivas. 3. ed. Rio de Janeiro: [s.d.], 1895.

5. ARANHA, Graça. $O$ meu próprio romance. São Paulo: Nacional, 1931.

6. ASSIS, Machado de. Crônicas. São Paulo: Mérito, 1959.

7. . A semana. São Paulo: Mérito, 1959.

8. AUGUSTA, Nísia Floresta Brasileira. Conselhos à minha filha. 2. ed. Rio de Janeiro: Tipografia Imparcial, 1845.

9.

Discurso que às suas educandas proferiu em 18 de dezembro de 1847. Rio de Janeiro: Tipografia Imparcial, 1847.

10. ___ Opúsculo humanitário. Edição atualizada com introdução e notas de Peggy Sharpe Valadares. (mimeogr.).

11. BARROSO, Francisco. A mulher. $A$ mensageira; revista literária dedicada à mulher brasileira, São Paulo, v. 1, n. 14, p. 220 - 223, abril 1898. ( Edição facsimilada. São Paulo: Imprensa Oficial, 1987. 2v.)

12. BELMAN, E. Moça prendada. In: LEITE, Míriam Moreira(org.) A condição feminina no Rio de Janeiro; século XIX. São Paulo: Hucitec; Brasília: Instituto Nacional do livro, 1984.

13. BELO, Oliveira. A instrução e o século. Revista do Partenon literário, Porto Alegre, v. 1, n. 1, jan. 1875.

14. BENJAMIN, Walter. Magia e técnica, arte $e$ política; ensaios sobre literatura e história da cultura. Trad. Sérgio Paulo Rouanet. São Paulo: Brasiliense, 1985.
15. BOSI, Ecleía. Memória e sociedade. São Paulo: T. A. Queiroz, 1981.

16. D., M. P. C.. A nossa condição. $A$ mensageira; revista literária dedicada à mulher brasileira. São Paulo, v. 1, n. 4, nov. 1897. ( Edição facsimilada. São Paulo: Imprensa Oficial, 1987. 2.v.)

17. DEBRET, Jean Baptiste. Viagem pitoresca $e$ histórica ao Brasil. Trad. Sérgio Milliet. São Paulo: Martins, 1954. 2.v.

18. EXPILLY, Charles. Mulheres e costumes do Brasil. São Paulo: Nacional, 1935.

19. FERREIRA, Joaquim. Verdadeiro método de estudar por Luís Antônio Verney. Porto: Domingos Barreira, [s.d.].

20. KIDDER, Daniel; FLETCHER, J.C. O Brasil $e$ os brasileiros; esboço histórico e descritivo. SãoPaulo: Nacional, 1941.

21. KOSTER, Henry. Viagens ao nordeste do Brasil. Trad. Luiz da Câmara Cascudo. São Paulo: Nacional, 1942.

22. LAMBERG, Moritz. Educação diferenciada. In: LEITE, Miriam Moreira (org.). $A$ condição feminina no Rio de Janeiro; séc.XIX. São Paulo: Hucitec; Brasília: Instituto Nacional do Livro, 1984.

23. LUCCOCK, John. Notas sobre o Rio de Janeiro e partes meridionais do Brasil. Trad. Milton da Silva Rodrigues. Belo Horizonte: Itatiaia; São Paulo: Edusp, 1975.

24. MANET, Edouard. Lettres de jeunesse (1848 - 1849); Voyage à Rio. Paris: Louis Rouart \& Fils, 1928.

25. RIO, João do. O momento literário. Rio de Janeiro: Garnier, [s.d.]. p. 23: Um lar de artistas.

26. SOUSA, Cruz e. Poesia Completa. Florianópolis: Fundação Catarinense de Cultura, 1981. p. 249 - 251: Saudação.

R. Est. Lit. Belo Horizonte, v. 1, n. 1, p. 31 - 47, out. 1993. 
ENSAIO

27. VERÍSSIMO, José. A educação Nacional. 3. ed. Porto Alegre: Mercado Aberto, 1985.

28. Estudos de literatura brasileira. Belo Horizonte: Itatiaia; São Paulo: Edusp, 1977. p. 46: Das condições da produção literária no Brasil. ( $3^{\mathrm{a}}$ série).

\section{RÉSUMÉ}

Cet essai a pour but l'étude de l'éducation des femmes au Brésil dans la seconde moitié du XIX ème siècle, aussi bien que la création et l'ascension d'un public de lectrices manipulé par des écrivants. 